\title{
Examination of the cost ratio of the formwork
}

\author{
Zs. Huszár ${ }^{1}$, É. Lublóy 2,"* \\ ${ }^{1}$ Budapest University of Technology and Economics, Department of \\ Construction Technology and Management, H-1521 Budapest, Hungary \\ ${ }^{2}$ Budapest University of Technology and Economics, Department of \\ Construction Materials and Technologies, H-1521 Budapest, Hungary \\ *e-mail:lubloy.eva@epito.bme.hu
}

Submitted: 19/02/2021; Accepted: 12/03/2021; Published online: 19/03/2021

Abstract: In case of construction investments, the cost estimation was always important. The reason for this is that after the planning, the most important issue is the cost of the investment. There are many different estimation methods. These estimates may vary in depth, depending on the task and the plan. The question is what happens if we wanted to predict not only the total cost of the investment but also the cost of some parts and structures. Such a cost element is the formwork cost of the monolithic reinforced concrete structures. This is a special processing aid, which makes it difficult to calculate accurately. The study is based on a cost analysis of the construction of 22 completed buildings over the last 10 years. Here, the cost of the formwork was compared to the total cost of the construction. By examining the 22 buildings together, we made findings over the years. We wanted to find out how much the construction price changes affected the structure and the formwork costs. The other direction of our research was the cost analysis within each building type, focusing on the formwork. In this analysis, we defined six types of buildings, such as detached, dwelling, condominium, public, office buildings, and other types of buildings. This study does not include the cost of the formwork types specific to each component, but from the foundation to the ascending structures, it analyses them in a single system.

Keywords: formwork; cost ratio; buildings 


\section{Introduction}

The three most frequently asked questions for construction investment are what, when and for what cost. The price has always been one of the most important from these three questions. That is why we are focusing on this issue.

The total cost of a construction investment is made up of three major cost categories. The first is the construction cost. This includes material, fee and machinery costs, as well as closely related additional costs such as freight or material management costs [1].

The second major cost group is the additional cost. This is not directly related to the construction work, but it has a connection to it. These include design costs, such as the cost of pre-studies, cost of geodesic-soil mechanics measurements, or legal costs.

The third major cost category is also an additional cost. It can be projected on a per square meter basis for construction costs, such as interior design, mobiles, or lump sum, or using some special technology, such as kitchen technology or warehousing.

In this paper, we have examined the cost of formwork, reinforcement and concreting of the 3 main building stages of the reinforced concrete construction in case of different types of buildings [2]. These were compared to the other phases of work and to the total cost. From the three main elements, the formwork is the only one which can be treated as a temporary structure, meaning that it is not presented in the final product [3]. At the same time, it is a significant cost factor, but its amount cannot be calculated precisely, because the amount of the material used during the construction, rarely matches the amount of the actual formwork [4].

Calculations prove that the calculated and actual formwork requirements are the same for a one-storey building with a floor area of one to two hundred square meters. In case of other buildings, large differences may occur, resulting in a deviation from the projected cost estimate. We will examine the possible causes of these differences in the context of this paper.

\section{Literature review}

\subsection{What does modern formwork mean?}

The formwork was already known in ancient times as a processing aid for making and supporting arch belts. The real major step in the formwork was the invention of reinforced concrete in the middle of the $19^{\text {th }}$ century. With the development of 
reinforced concrete, the formwork has played an important role in the surface formation besides the supporting task so far.

By the turn of the century, the development of the formwork had already begun. It has become clear that formwork requires the most work from reinforced concrete works, ahead of concreting [5].

The next major development had begun at the end of World War II. This is mainly due to the increased demand for preformed reinforced concrete structures [6]. Sliding formwork and climbing formwork [7] were created and by the end of the 1960s the large - scale formwork system had become widespread [8].

However, in the current construction industry, attitudes have changed again. The quantitative attitude after the world war was replaced by customized construction [9]. Companies specializing in certain types of construction work have been transformed and their activities had expanded. This change has also brought great advances in the formwork industry [10]. The so-called multi-purpose, modern formwork systems have been created. In contrast to the earlier ones, this formwork was already universal and extensive [11]. The same type of formwork can be used for shuttering a dwelling house or even a hydroelectric power plant. These formworks combine small-scale and large-scale formwork [12]. The boards can be used to assemble large panels of up to $30-40 \mathrm{~m}^{2}$ with quick clamps [13].

The application of automation and robotics in construction industry, has shown significant growth inrecent decades with examples to include, among others, adaptive casting techniques [14] whose application appears in various robotic tasks. Robots have been mostly applied for the development of complex and non-standard structures with highly customized and variable morphologies and in cases where conventional construction approaches would be less feasible and cost-effective [15]. Such applications include, among others, robotic casting, additive manufacturing and 3D printing.

\subsection{Formwork}

The types of formwork can be grouped in many different ways, such as vertical or horizontal formwork, based on their size or material characteristics. In this study, the cost analysis of the formwork is the main guideline, so following types of formwork will be examined [16]:

- formwork for substructures,

- formwork for ascending structures,

- wall formwork,

- pillar formwork, 
- beam and pillar formwork,

- slab formwork,

- stair formwork.

Formwork for substructure works generally uses a lightweight steel framed formwork system with a plywood shell structure and a relatively small number of element widths that can be moved manually without a crane. Typically, such structures were used for grounding formwork in the examined buildings. An exception to this, are a few family houses that use traditional slatted sidewall formwork [17].

Formwork of rising structures are wall formwork, pillar formwork, beam formwork, slab formwork and stair formwork.

Thinking of a modern formwork system, formwork can be divided into two main groups based on their structure: large-panel wall formwork with wooden box and framed formwork systems [18].

- Large panel wall formwork with wooden box: in its structural principle, it rather evokes the past in a modern robe. It means that, instead of the classic wall brackets, modern glued I-section timber brackets take the load and pass it on to modern double $\mathrm{U}$ profile cross brackets. The shell is a glued laminated board, phenol coated but with free edges [19].

- Framed formwork systems: typically, plywood enclosed in a steel support frame with a formwork. A wide variety of board widths (usually in $10-15 \mathrm{~cm}$ raster jumps), systems with high level $(270-300-330 \mathrm{~cm})$ and half-height $(120-150 \mathrm{~cm})$ elements with quick-release clips. Crane or hand-operated structures (in the case of high-rise boards they are aluminium framed) [20].

Pillar formwork, like wall formwork, can be divided into two large groups based on their structure: wooden boxes and frame structure. In case of framed systems, the boards have special bridges. It means that the bridging is possible not only at the edges, but the boards are perforated in $5 \mathrm{~cm}$ scales. In this way with a $75 \mathrm{~cm}$ wide board, we can create a $30 \times 30 \mathrm{~cm}$ or even $60 \times 60 \mathrm{~cm}$ pillar with a butterfly bond. Of course, in a plugged it in state, these special boards can also be used as a standard formwork element.

Among the slab formwork in Hungary, the most common formwork system is the wooden slab system. Its structure is based on a simple, main and drawer system. the final transfer of load is made through the steel supports to the lower slab.

Usually, the main and drawer are glued wooden boxes supports of the same cross section with an "I" profile design. The concrete surface of the formwork consists of 
wooden formwork boards. It is used with a three-layer glued pine design, but phenolcoated plywood is also common. Because the connection of the wooden supports is not fixed, only laid, and overlapped, therefore, it is very easy to follow the formwork of structures with varied geometry. Of course, the aluminium-framed slab formwork system and its drop-in version are also used, but because of its framework, its geometric possibilities are more knitted.

In case of stair formwork, the base frame is the same as the wood support system, but its cover can be a cut formwork board or a plank in case of stairs with drawn arms.

\section{Evaluation method}

The data is based on the specific contractor budget for each building. Their quantitative data set was obtained from designers' budget. The data is the cost taken from the detailed contractor budget, which includes material and labour costs. For each building, we collected the costs of the formwork, reinforcing, and concreting from my total budget. The sum of these amounts shows the total cost of the structure.

Each building is listed in a separate database with the relevant structural cost tables. In the summary worksheet, the rows contain the examined buildings ( 22 in total). The columns contain the calculated quantities for the various test items, broken down by type of structure and formwork, with material quantities and cost (in HUF) data.

In the current study, we analysed the cost of the structural constructions within the first major cost group, and within that, the cost and proportion of the formwork.

Earlier statistics showed that the $40 \%$ of the total construction was the formwork activity. To analyse this, we examined 22 buildings. The examined buildings can be classified into six main categories according to their type. The categories are:

- detached,

- dwelling,

- condominium,

- public building,

- office building,

- and other types of buildings.

For the sake of accuracy, here is what we mean by each group:

- Detached house: in general, a single-family residential building, typically with a loft, usually with a maximum of two levels of monolithic reinforced 
concrete slabs, depending on the characteristics of the basement. Typical groundworks are beam-reinforced slate, with a relatively thin but sized reinforced base plate, which works as a structure working with the ironed base beams. Its load-bearing structure is a masonry structure with reinforced concrete wooden pillars due to the new MSZ EN [21] (Eurocode) scaling. The wreath of the reinforced concrete appears as a separate structure (not built in the slab), typically in loft structures.

- Dwelling house: It is typically larger, it has one or two floors, with 2-3 monolithic reinforced concrete slabs, but still with load-bearing masonry, with few reinforced concrete pillars.

- Condominium: They are reinforced concrete pillar buildings. They have 3-6 floors with monolithic reinforced concrete slabs, reinforced concrete with staircase, elevator shaft and reinforcing walls, typically with base plate foundation.

- Public building: In these category 4 buildings were analysed. They include an educational building, a new hospital wing, and a rehabilitation and early development centre. Their structure is quite mixed, basically pillar buildings, but in some of them the monolithic reinforced concrete façade wall system is dominant. Each of them is made of monolithic reinforced concrete slabs with different thickness.

- Office buildings: These are modern, pillar buildings with monolithic reinforced concrete slabs, reinforced walls and filling ceramic masonry. They are based on metal, with some deep ground (piles).

- Other types of buildings: This group includes the construction of a new wing of a kindergarten, the construction of a new temple, and a yoga house of a smaller condominium. They are typically masonry with a monolithic reinforced concrete slab, reinforced strip, or thin reinforced concrete slab.

The authors examined the period of construction from 2007 to 2017 , so the last 10 years. Of course, this includes the crisis period of the Hungarian construction industry and the booming time of the last 3-5 years. It is important that in the study, the interpretation of structure construction refers to the construction of monolithic reinforced concrete structure, so for works on concrete and reinforced concrete.

These are the following:

- Flat base groundwork: slate slabs, beam grid, sheet base, head beam, slate base wreath, dimensioned reinforced based concrete (thin slab base), 
- Rising vertical structures: concrete and reinforced concrete walls, blade walls and reinforced concrete pillars,

- Rising horizontal structures: reinforced concrete slabs, coffin slabs, reinforced concrete beams, wreaths, etc. stair structures.

The above-mentioned threefold classification is also valid from the structural side. However, in our study, we make this triple categorization for the use of formwork for the following consideration. The main difference between vertical and horizontal formwork is the time of formwork, i.e. the rate of formwork rotation. In case of vertical structures, it can be rotated in 24-hour daily cycles. This means that the same structure can be concreted again, whereas for horizontal structures this is usually 57 days for shuttering time. Of course, this is greatly influenced by the type of structure, the thickness of the structure, the quality of the concrete, the weather, and many other factors. In this case, we do not deal with special slab formwork systems, where this formwork time can be reduced to 48 hours.

However, the flat base groundwork is not considered to a separate category because of the formwork time, this is due to the volume ratio of formwork to the concrete. These structures have three main cost components: formwork, rebar installation, and concreting.

Our examinations were carried out in three stages:

- We analysed the average formwork cost per square meter of all 22 buildings over the years.

- We examined the ratio of total formwork costs related to the structure, over the whole sample (22 buildings).

- We examined the ratio of total formwork costs related to the complete construction in case of every building types.

In the summary table, we collected the quantities of the typical formwork types for every building. To this we added material and labour fees.

Analysing the budget of the 22 examined buildings, as well as the construction technology of the completed buildings, it can be concluded that each building was built with a modern formwork system. So, the results are relevantly comparable.

\section{Definition of the calculated quantities}

According to any of the Hungarian norms, it can be said that the quantity of the formwork surface is based on the actual size of the formwork contacting the concrete and reinforced concrete structures. Based on the measurement rule, apertures greater 
than $1,0 \mathrm{~m}^{2}$ in the formwork shall be subtracted. However, the cross-beam formwork of such apertures shall be added to the area. These sizes are calculated from static plans.

The first important question is: What do formwork costs include?

The so-called two-post budgeting is very common in Hungary. This is divided into material and labour, based on resource requirements. The budget of the 22 buildings I examined is also a two-column budget. The three resource needs are the followings:

- time requirements: This is in national and industrial standards, in technical guidelines or regulations a time required operation grouped by professions. An important part is preparation, handling, servicing, incorporation, and post treatment etc.

- machine work requirements: Suitable for performing the operations and the work requirements of the most typical construction machinery under domestic conditions, detailed as machine types, and expressed in shifts.

- material requirement: to produce the amount of structure a technically justified and standardized material standard is required.

\subsection{What does modern formwork mean?}

The fee is a time requirement, so the standard time and the exact value multiplied by the calculated quantity (formwork surface). In generally the value of the machine work requirement is expressed in the fees.

Speed of erection, safety, cost-efficiency, and flexibility are among the attributes of modern formwork systems. Modern formwork and scaffolding systems are attractive for their speed of erection, safety, cost-efficiency, and flexibility.

\subsection{Material cost}

However, calculating the cost of materials is not an easy task. The material requirements for reinforcement and concreting are part of the final structure. Their quantitative calculations can be handled exactly based on construction and static plans. In contrast, only the surface of the formwork can be accurately calculated in terms of the amount of formwork. According to the above-mentioned rules, the amount of formwork used at the construction site is the formwork rotation. This is a variable value depending on its efficiency that needs to be optimized. Therefore, the specific cost per square meter of the formwork is not the price of the formwork lease, or the percentage of the purchase price. It is a number calculated from the result of a scheduled, formwork plan. 


\section{Definition of the calculated quantities}

Based on the Hungarian Central Statistical Office data, it can be stated that in the construction industry, between 2007 and 2017, the construction materials and labour prices showed an increasing tendency. Fig. 1 shows the variation of the average formwork cost per square metre in case of the 22 buildings we examined over the years.

It can be stated that Fig. 1 shows two very low formwork prices per square meter. In the category of the small house the price was $3,920 \mathrm{HUF} / \mathrm{m}^{2}$ and in the other category the construction of a yoga house was $3,088 \mathrm{HUF} / \mathrm{m}^{2}$. Both construction projects are related to the year 2017, where the average price of the other seven buildings was $6,583 \mathrm{HUF} / \mathrm{m}^{2}$. It can be explained by a mispriced unit price, which is smaller and in case of an individual building is a typical preparation error. It occurs when there is no shutter roll plan and no execution time schedule, consequently, the price per square meter is either a number generated from the budget software database or a value "taken over" from a previous construction.

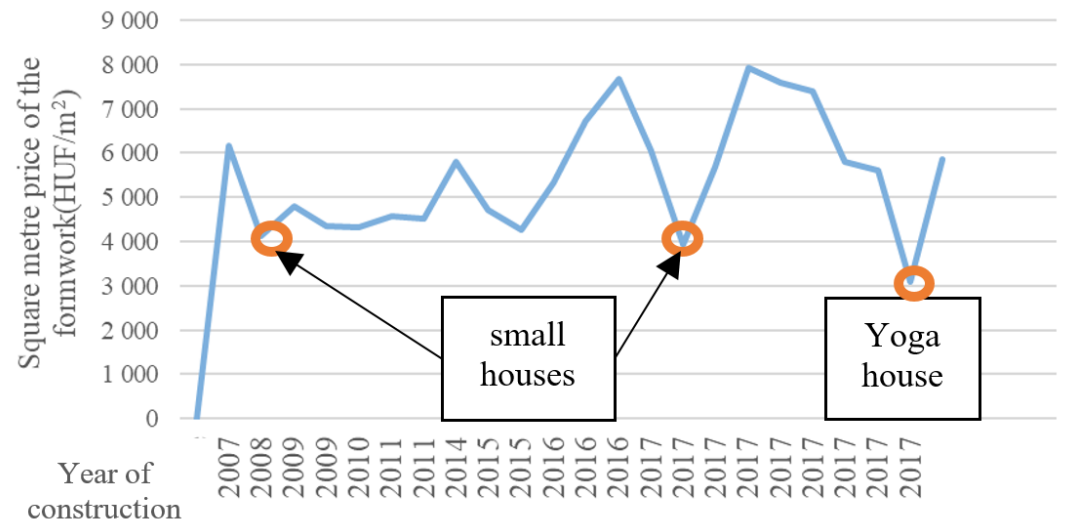

Figure 1. Change of the cost of the average formwork per square metre over the years

\subsection{Structural formwork cost ratio for the whole structure}

In the first examination, we analysed the ratio of total monolithic reinforced concrete structural cost to the total formwork cost, regarding to the building type for all buildings.

The average value is $30 \%$, which is much lower than the previous statistics. One reason for this is the big change in the economy in the 1990s. From this time, the 
imported goods into Hungary had no longer dependence from the large foreign trade companies, but the goods could be bought independently by anyone from a foreign manufacturer.

This was also the case with the modern formwork systems, which subsequently came to Hungary in large quantities. It has significantly reformed the system of the formwork use and its reproduction. Domestic subsidiaries of well-known European formwork companies were established. As a result of it, the market for formwork systems were created in Hungary and the concept of formwork rental. This new concept, both economically and technically, has increased the importance of the formwork, therefore, not only did the contractors use their own formwork as before. They became part of a rent-based, profit-oriented system.

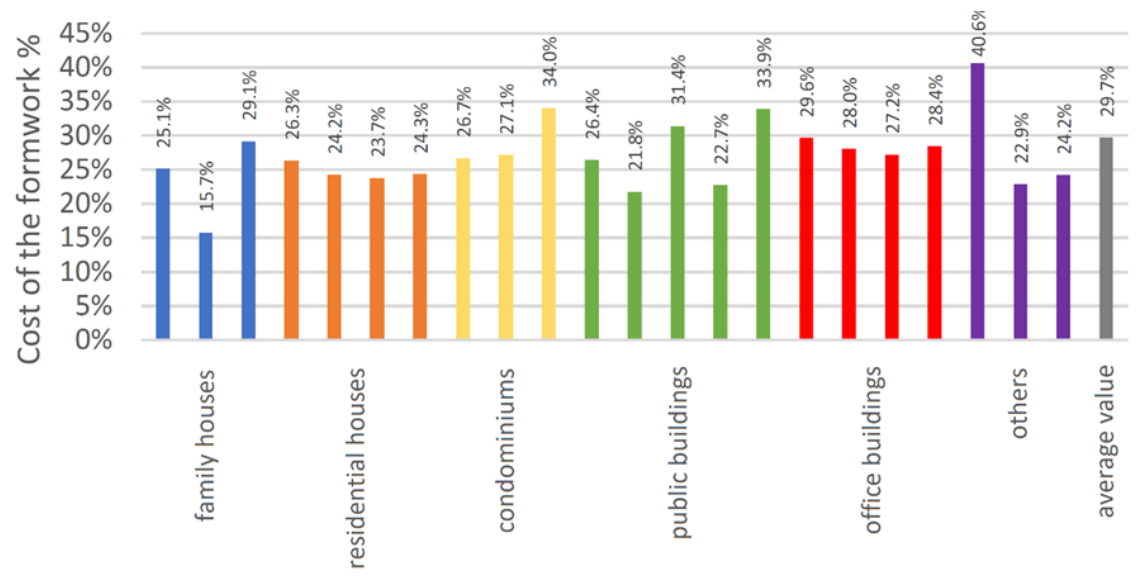

Type of the buildings

Figure 2. Proportion of the total formwork costs of all examined buildings related to the whole building structure

As a result of two factors, namely the use of rental formwork and the use of modern formwork systems, it can be concluded that much less formwork is now being used in the same time as in the system based on planned economy. It means that there is a lower cost ratio on the formwork side for the whole construction.

Analysing the Fig. 2, we can see that the average 30\% shuttering cost for the whole building type shows quite large fluctuations between $16 \%$ and $41 \%$. Therefore, the results were also examined by building types. If there is a significant deviation from $30 \%$ then real costs need to be reviewed there. Thanks to this, we have developed a new method for the approximate control of formwork costs. 


\subsection{The rate of the construction cost of the formwork for the total structure for all building types}

Analysing the Fig. 3a and 3b, the extremely low rate of the formwork $(16 \%)$ in case of family houses has two main causes. One is that the building has a one-storied reinforced concrete slab, without reinforced concrete walls. The other reason is that due to the poor subsoil (because it was built on a former cornfield), the building is built on a disproportionately large base. It has a specific need for the formwork. However, the uptake of concrete and the reinforcing steel is high, so they distort the rates of the formwork.

Conclusion: in the category of detached houses and residential buildings, the average formwork cost is $24-25 \%$ of the whole structural construction costs. This represents a 5-6 percent reduction over the average cost of $30 \%$ of all 22 buildings. The reason is that the vertical structures of both the detached house and the residential building types were made of load-bearing masonry. These houses contain very few reinforced concrete pillars.

Perhaps the most consistent values were for the condominium category (Figure 4a) and in case of the office buildings (Fig. 5a). Here the deviation from the average is plus or minus $3-4 \%$. The explanation for it can be found in the relatively homogeneous pillar structures, where no large specific differences are expected.

In case of public buildings (Fig. 4b), two extremely low values are found, which are $22 \%$ and $23 \%$.

The explanation for it could be the following:

- This could be explained by the formwork surface area per cubic meter. In case of the 22 buildings, the formwork area per cubic meter of the concrete is an average of 4.63 formwork $\left(\mathrm{m}^{2}\right) /$ concrete $\left(\mathrm{m}^{3}\right)$. For the two buildings with extremely low value, these rates are 4.18 and $4.04 \mathrm{~m}^{2} / \mathrm{m}^{3}$, which is more than $10 \%$ under the average.

- The other explanation is the rate of the reinforced concrete and the formwork prices tested in the current year. We have examined the change in cost ratio compared to the date of the construction. In terms of 22 data, the first building was completed in 2007 and the last in 2017. Prices did not change linearly. It can be stated that the lowest prices were in the crisis years of 2008-2009, while the highest ones were in the year of 2017. The increase was $70 \%$ in 10 years, but in 2011 it was also outstanding value.

What is interesting about the measurements is that the prices of formwork and reinforced concrete structures have changed similarly over the years. On average, 
the cost of reinforced concrete per cubic meter is 12 times more than the cost of formwork per square metre. This rate is also shown in 2007, 2015 and 2017.

In case of the two above-mentioned public buildings, where we look for the rates of very low formwork and total construction costs, we can see that, compared to the average number (12), the cost of the reinforced concrete per cubic meter is 14 and 15 times more expensive than the formwork cost per square meter. This explains the low (below average) value of the formwork cost ratio of the tested structure construction for the whole structure.

In the last graph, (Fig. 5b), we examined the rate of the "other" buildings' formwork costs related to the structure of the entire building. The buildings under examination, for example kindergarten, temple, and yoga house, cannot be classified into the above-mentioned categories so they are included in the group of "other". It is clear from the graphs that their formwork costs need to be examined on an individual way. We cannot say general statements for it.

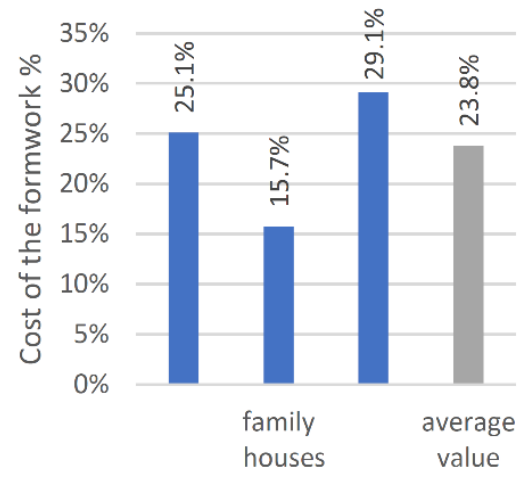

a)

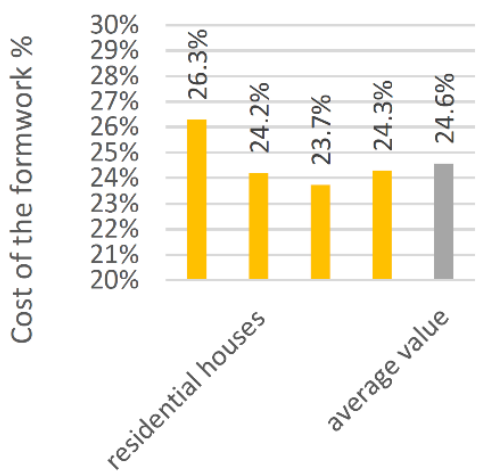

b)

Figure 3. Proportion of the formwork costs according to the structure of the whole building a) in detached houses $b$ ) in residential houses 


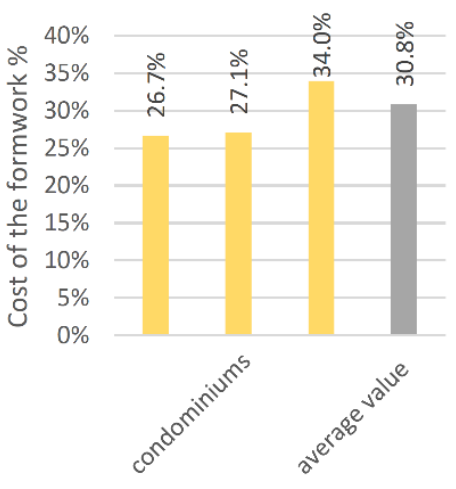

a)

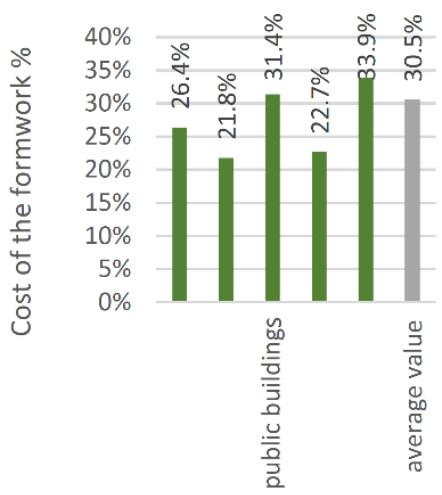

b)

Figure 4. Proportion of the formwork costs according to the structure of the whole building a) in condominiums $b$ ) in public buildings

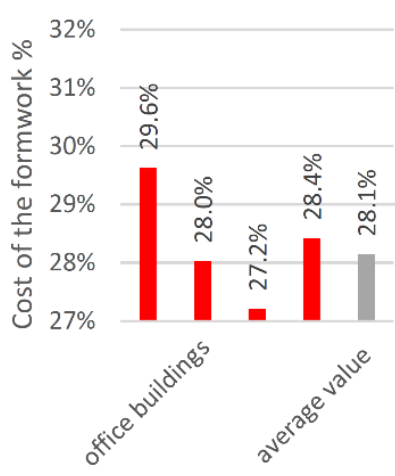

a)
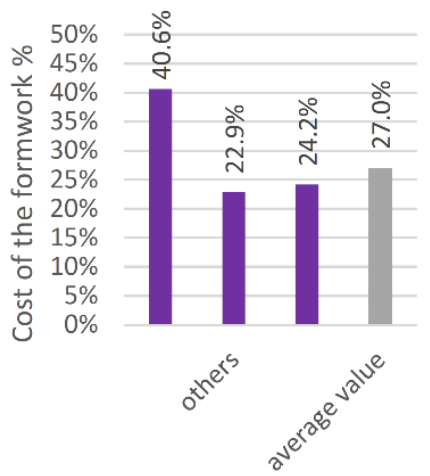

b)

Figure 5. Proportion of the formwork costs according to the structure of the whole building $a$ ) in office buildings $b$ ) in other type of buildings

In the last graph, (Fig. 5b), we examined the rate of the "other" buildings' formwork costs related to the structure of the entire building. The buildings under examination, for example kindergarten, temple, and yoga house, cannot be classified into the above-mentioned categories so they are included in the group of "other". It is clear from the graphs that their formwork costs need to be examined on an individual way. We cannot say general statements for it. 


\section{Conclusions}

The purpose of this paper was to estimate the cost of the formwork for each type of building as defined by the authors in relation to the whole structure. To reach this goal, we analysed the construction and implementation budgets of 22 buildings made in recent years in tabular and graphic form. The numerical results of the measurements show that the recent drastic increases in construction prices (especially in the last 3-5 years) do not apply to structural construction so significantly. So, this is a projected price estimate for the future, with much greater accuracy.

Another important result of the paper is that based on the concrete measurements and calculations, we have now obtained real rates for the formwork costs. One of the utilise possibilities of this result is that the total cost of the structure can be calculated with a good engineering estimate from the amount of calculated or known formwork surfaces.

Otherwise, it's inverse is also true. The type of the building also influences the cost ratio of the formwork to the total structural cost, especially in case of typing within residential buildings. Measurements show that the ratio is about $24-25 \%$ in case of the detached house and the house we have defined, until the average for condominiums is $31 \%$. It means that the cost of the formwork is higher in relation to the total cost of the construction for multi-storey residential buildings than for one or two apartment buildings.

\section{References}

[1] L. Wéber, How much should I undertake - a handbook on building construction pricing (Mennyiért vállaljam - kézikönyv az építőipari árak képzéséről) (Terc, 2008). (in Hungarian).

[2] Á. Takács, L. Neszmélyi. M. Somogyi, Construction and Construction (Építéskivitelezés -szervezés) Szega Books, (2007) (in Hungarian).

[3] F. H. Hoffmann: Schalungstechnik mit System Bauverlag, Berlin, (1993) (in German), p.138.

[4] L L. Neszmélyi, Budget and pricing in the construction industry (Költségvetés és árképzés az építőiparban) - TERC Kft., Budapest, (2013) (in Hungarian).

[5] Á. Paládi-Kovács, Decorative concrete surface design, Periodica Polytechnica Civil Engineering 47 (1) (2003) pp. 57-61. doi: https://pp.bme.hu/ci/article/view/598 
[6] M. S. M Rahim, A. H. Nuzul, Construction Cost Comparison Between Conventional and Formwork System for condominium Project, IJASCSE 2 (5) (2013) pp. 19-23.

[7] K. Kumarasivam, Industrialisation in Housing Construction, Toward Industrialisation in the Building Industry, Proceeding of a UNESCO/FIESEAP regional Workshop at UPM. (1986) p.65.

[8] K. Collier, Estimating Construction Cost: A Conceptual Approach Reston Publishing Company Inc., Reston, Virginia (1990.)

[9] Y. F. Badir, M.R.A Kadir, A.A.A Ali, Theory of Classification and BadirRazali Building Systems Classification, Buletin Bulanan IJM, Jurultera, Oct, (1989), pp. 50-56.

[10] K. Andor, A. Lengyel, R. Polgár, T. Fodor, Z. Karácsonyi, Experimental and Statistical Analysis of Formwork Beams Reinforced with CFRP, Periodica Polytechnica Civil Engineering 63 (1) (2019) pp. 184-191. doi: https://doi.org/10.3311/PPCi.13057

[11] K . Gwang-Hee, A. Sung-Hoon, C. Hun-Hee, S. Deok, K. Seo, K. In, Improved productivity using a modified table formwork system for high-rise building in Korea, Building and Environment 40 (11) (2005) pp: 1472-1478. doi: https://doi.org/10.1016/j.buildenv.2004.06.023

[12] D. Mansuri, D. Chakraborty, H. Elzarka, A. Deshpande, T. Gronseth, Building Information Modeling enabled Cascading Formwork Management Tool, Automation in Construction 83 (1) (2017) pp. 259-272. doi: https://doi.org/10.1016/j.autcon.2017.08.016

[13] L. Dongmin, L. Hyunsu, K Taehoon, C. Hunhee, K. Kyung-In, Advanced planning model of formwork layout for productivity improvement in high-rise building construction, Automation in Construction, 85 (2) (2018) pp. 232 240.

doi: https://doi.org/10.1016/j.autcon.2017.09.019

[14] T. Bock, Construction Automation and Robotics, in book Robotics and Automation in Construction, (2008) pp. 21-42. doi: https://doi.org/10.5772/5861

[15] De Schutter et al., Vision of 3D printing with concrete - technical, economic and environmental potentials, Cement Concr. Res., 112 (2) (2018), pp. 25-36. doi: https://doi.org/10.1016/j.cemconres.2018.06.001 
[16] H. Rong-yau, C. Jeam-Jei, S. Kuo-Shun, Planning gang formwork operations for building construction using simulations, Automation in Construction 13, (6) (2004), pp. 765-779.

doi: https://doi.org/10.1016/j.autcon.2004.05.001

[17] S. Teixeira, A. Santilli, I. Puente, Analysis of casting rate for the validation of models developed to predict the maximum lateral pressure exerted by selfcompacting concrete on vertical formwork, Journal of Building Engineering 6 (1) (2016), pp. 215-224.

doi: https://doi.org/10.1016/j.jobe.2016.03.008

[18] J. H. M. Tah, A. D. F. Price, Interactive computer-aided formwork design, Computers \& Structures 41, (6) (1991) pp. 1157-1167.

doi: https://doi.org/10.1016/0045-7949(91)90253-I

[19] R. Dodge Woodson, Chapter 5 - Concrete Formwork, Editor(s): R. Dodge Woodson, Concrete Portable Handbook, Butterworth-Heinemann, 2012, pp. $41-46$.

[20] R. M. W. Horner, D. C. Thomson, Relative costs of site-made and proprietary formwork, Building and Environment 16 (4) (1981) pp. 243-250. doi: https://doi.org/10.1016/0360-1323(81)90002-0

[21] Design of concrete structures (General rules for buildings) MSZ EN 1992 (2005). 